\title{
Syntheses, structural characterization, and thermal behaviour of metal complexes with 3-aminopyridine as co-ligands
}

\author{
Franz A. Mautner ${ }^{1}$ (D) Patricia V. Jantscher ${ }^{1} \cdot$ Roland C. Fischer $^{2} \cdot$ Ana Torvisco $^{2} \cdot$ Klaus Reichmann $^{3}$. \\ Salah S. Massoud ${ }^{4}$
}

Received: 23 September 2020 / Accepted: 31 October 2020 / Published online: 17 November 2020

(c) The Author(s) 2020

\begin{abstract}
Six mixed metal complexes with 3-aminopyridine (3-ampy) as a co-ligand have been synthesized: catena-\{ $\left[\mathrm{M}\left(\mu_{2}-3\right.\right.$-ampy) $\left.\left.\left(\mathrm{H}_{2} \mathrm{O}\right)_{4}\right] \mathrm{SO}_{4} \cdot \mathrm{H}_{2} \mathrm{O}\right\}(M=\mathrm{Ni}(\mathbf{1})$ and $\mathrm{Co}(\mathbf{2})),\left[\mathrm{Co}(3-\mathrm{ampy})_{4}(\mathrm{NCS})_{2}\right](\mathbf{3}),\left[\mathrm{Co}(3-\mathrm{ampy})_{2}(\mathrm{NCS})_{2}\right](\mathbf{4}),\left[\mathrm{Co}(3-\mathrm{ampy})_{4}\left(\mathrm{~N}_{3}\right)_{2}\right](\mathbf{5})$ and $m e r-\left[\mathrm{Co}(3 \text {-ampy })_{3}\left(\mathrm{~N}_{3}\right)_{3}\right](\mathbf{6}),\left(\mathrm{NCS}^{-}=\right.$isothiocyanate ion, $\mathrm{N}_{3}{ }^{-}$azide ion), and characterized by physio-chemical and spectroscopic methods as well as single crystal X-ray and powder diffraction. In the isostructural complexes $\mathbf{1}$ and $\mathbf{2}$ single $\mu_{2}$-3-ampy links the $\mathrm{Ni}$ (II) and $\mathrm{Co}$ (II) centers into polymeric chains. The mononuclear $\mathrm{Co}$ (II) and $\mathrm{Co}(\mathrm{III})$ pseudohalide complexes 3-6 reveal only terminal 3-ampy ligands. The 3-ampy ligands form supramolecular hydrogen bonded systems via their $\mathrm{NH}_{2}$-groups and non-covalent $\pi-\pi$ ring-ring interactions via their pyridine moieties. Thermoanalytical properties were investigated for $\mathbf{1} \mathbf{- 3}$.
\end{abstract}

\section{Introduction}

Aminopyridine ligands have been extensively studied in the synthesis of many coordination metal compounds ranging from simple mononuclear to coordination polymeric compounds (CPs) with different dimensionality. The construction of CPs is attributed to the intriguing structural diversity and the dual functionality of these ligands, which may lead to the formation of 1D or 3D structures [1-19], especially in the presence of other potentially bridging ligands such as pseudohalides [1-3, 13]. Another feature incorporated in this class of compounds is their affinity to show different

Electronic supplementary material The online version of this article (https://doi.org/10.1007/s11243-020-00436-2) contains supplementary material, which is available to authorized users.

Franz A. Mautner

mautner@tugraz.at

1 Institut für Physikalische und Theoretische Chemie, Technische Universität Graz, 8010 Graz, Austria

2 Institut für Anorganische Chemie, Technische Universität Graz, 8010 Graz, Austria

3 Institut für Chemische Technologie von Materialien, Technische Universität Graz, 8010 Graz, Austria

4 Department of Chemistry, University of Louisiana at Lafayette, Lafayette, LA 4437070504, USA hydrogen bonds, $\mathrm{N}-\mathrm{H} \cdots \mathrm{X}$ between the amino $\mathrm{NH}$ and a coordinated pseudohalide (X), which tends to extend the structure from 1D to a 3D network. Extra stability can also be generated through $\pi-\pi$ stacking interactions between the aromatic pyridyl ligands, which play an important role in stabilizing the resultant polymeric architectures $[1-3,9,15$, 16].

3-Aminopyridine (3-ampy) as one of the aminopyridine series is a simple molecule which can act as mondentate ligand by binding the metal ions in the most common binding mode via the most basic $N$-pyridyl nitrogen (II) $[2,7,15,19-35]$ or the least likely binding site of the amino group (III) $[33,34]$. The latter bonding mode can also be achieved through the $\mathrm{N}$-amino donor site of the pyridinium ion (IV) [24, 38, 39]. Moreover, the molecule can also, simultaneously bridging two metal ions via the $N$-pyridyl and $N$-amino donor atoms (I) [1-17]. Different binding modes of the 3-aminopyridine ligand are summarized in Scheme 1. In some complexes, the 3-ampy was reported to behave as monoprotonated 3-aminopyridinium cation [24, 38, 40-43] or as doubly protonated 3-ammonium pyridinium dication $[44,46]$. In an attempt to explore the coordination chemistry (nuclearity, CPs, dimensionality, hydrogen bonding and non-covalent interactions) of 3-ampy with metal ions ( $\mathrm{Co}(\mathrm{II}), \mathrm{Ni}(\mathrm{II})$, and $\mathrm{Co}(\mathrm{III}))$ in the presence of potentially bridging pseudohalide ligands $\left(\mathrm{N}_{3}{ }^{-}=\right.$azide anion and $\mathrm{NCS}^{-}=$thiocyanate anion), the following study was undertaken. 
Scheme 1 Bonding modes of 3-aminopyridine (3-ampy)<smiles>[M]Nc1ccc[n+]([M])c1</smiles>

(I)<smiles></smiles>

(II)<smiles>[M]Nc1cccnc1</smiles>

(III)<smiles>[M]Nc1cccnc1</smiles>

(IV)

\section{Experimental}

\section{Materials and physical measurements}

3-aminopyridine was purchased from Aldrich. All other materials were reagent grade quality. Infrared spectra of the solid complexes were performed on a Bruker Alpha P (platinumATR-cap). UV-Vis-NIR spectra were recorded with a LS950 Perkin-Elmer Lambda-spectrometer. Thermal analyses were performed on solid samples with using NETSCH STA $\left(\mathrm{N}_{2}\right.$ atmosphere; heating rate $10^{\circ} \mathrm{C} / \mathrm{min}$ ). PXRD measurements of the microcrystalline bulk material were performed with a Bruker D8 Advance powder diffractometer. Elemental CHN microanalyses were carried out with an Elementar Vario EN3 analyzer.

\section{Synthesis of the compounds}

\section{Synthesis of catena- $\left\{\left[\mathrm{Ni}\left(\mu_{2}-3-\mathrm{ampy}\right)\left(\mathrm{H}_{2} \mathrm{O}\right)_{4}\right] \mathrm{SO}_{4} \cdot \mathrm{H}_{2} \mathrm{O}\right\}$ (1)}

$\mathrm{NiSO}_{4} \cdot 6 \mathrm{H}_{2} \mathrm{O}(0.263 \mathrm{~g}, 1 \mathrm{mmol})$, and 3-aminopyridine $(0.095 \mathrm{~g}, 1 \mathrm{mmol})$ were dissolved in $80 \mathrm{ml} \mathrm{H}_{2} \mathrm{O}$ at $90^{\circ} \mathrm{C}$. Upon slow cooling to RT blue crystals of 1 were separated after 2 days (yield: $0.24 \mathrm{~g}, 71 \%$ ). Anal. Calcd for $\mathrm{C}_{5} \mathrm{H}_{16} \mathrm{~N}_{2} \mathrm{NiO}_{9} \mathrm{~S}$ (338.95 g/mol): $17.7 \% \mathrm{C} ; 4.8 \% \mathrm{H} ; 8.3 \% \mathrm{~N}$; Found: $17.6 \% \mathrm{C}$; $4.8 \% \mathrm{H} ; 8.2 \% \mathrm{~N}$; IR (ATR, $\mathrm{cm}^{-1}$ ): 3162 (s, br), 1655 (w), 1612 (w), 1593 (w), 1560 (w), 1495 (w), 1455 (w), 1262 (w), 1077 (s), 1043 (s), 1021 (s), 905 (w), 836 (w), 810 (m), 778 (w), 745 (w), $697(\mathrm{~m}), 650(\mathrm{~m}), 609(\mathrm{~m}), 559(\mathrm{~m}), 423(\mathrm{w})$.

\section{Synthesis of catena- $\left\{\left[\mathrm{Co}\left(\mu_{2}-3-\mathrm{ampy}\right)\left(\mathrm{H}_{2} \mathrm{O}\right)_{4}\right] \mathrm{SO}_{4} \cdot \mathrm{H}_{2} \mathrm{O}\right\}$ (2)}

A procedure similar to that described for $\mathbf{1}$ was used to synthesize the pink needle-shaped crystals of $\mathbf{2}$ using $\mathrm{CoSO}_{4} \cdot 7 \mathrm{H}_{2} \mathrm{O}(0.28 \mathrm{~g}, 1 \mathrm{mmol})$ instead of $\mathrm{Ni}(\mathrm{II})$ salt (yield: $0.26 \mathrm{~g}, 77 \%)$. Anal. Calcd for $\mathrm{C}_{5} \mathrm{H}_{16} \mathrm{CoN}_{2} \mathrm{O}_{9} \mathrm{~S}(339.19 \mathrm{~g} /$ mol): $17.7 \% \mathrm{C} ; 4.8 \% \mathrm{H} ; 8.3 \% \mathrm{~N}$; Found: $17.5 \% \mathrm{C} ; 4.9 \% \mathrm{H}$;
8.4\% N; IR (ATR, $\mathrm{cm}^{-1}$ ): 3200 (s, br), 1655 (w), 1611 (w), $1591(\mathrm{w}), 1495$ (w), 1454 (w), 1262 (w), 1077 (s), 1010 (s), $905(\mathrm{w}), 810(\mathrm{w}), 724(\mathrm{w}), 680(\mathrm{~m}), 649(\mathrm{~m}), 613(\mathrm{~s})$, $554(\mathrm{~m}), 524(\mathrm{~m}), 418(\mathrm{w})$.

\section{Synthesis of $\left[\mathrm{Co}(3-\mathrm{ampy})_{4}(\mathrm{NCS})_{2}\right](3)$}

A mixture of $\mathrm{Co}\left(\mathrm{NO}_{3}\right)_{2} \cdot 6 \mathrm{H}_{2} \mathrm{O}(0.29 \mathrm{~g}, 1 \mathrm{mmol}), \mathrm{KSCN}$ (0.19 g, $2 \mathrm{mmol})$ and 3-aminopyridine $(0.38 \mathrm{~g}, 4 \mathrm{mmol})$ were dissolved in $130 \mathrm{ml}$ of distilled $\mathrm{H}_{2} \mathrm{O}$ at $75^{\circ} \mathrm{C}$ for about $15 \mathrm{~min}$. The hot solution was filtered while hot and then slowly cooled to RT. After six days, fine orange-red needle-shaped crystals were obtained (yield: $0.35 \mathrm{~g}, 64 \%$ ). Anal. Calcd for $\mathrm{C}_{22} \mathrm{H}_{24} \mathrm{CoN}_{10} \mathrm{~S}_{2}(551.56 \mathrm{~g} / \mathrm{mol}): 47.9 \% \mathrm{C}$; $4.4 \% \mathrm{H} ; 25.4 \% \mathrm{~N}$; Found: $47.7 \% \mathrm{C} ; 4.3 \% \mathrm{H} ; 25.6 \% \mathrm{~N}$; IR $\left(\right.$ ATR, $\left.\mathrm{cm}^{-1}\right)$ : $3405(\mathrm{w}), 3329(\mathrm{w}), 3283(\mathrm{w}), 3191(\mathrm{w})$, 3040 (w), 2083 (vs), 1621 (s), 1579 (s), 1485 (m), 1441 (s), 1342 (w), $1292(\mathrm{~m}), 1257(\mathrm{w}), 1190(\mathrm{w}), 1128(\mathrm{~m})$, $1084(\mathrm{w}), 1047(\mathrm{~m}), 1023(\mathrm{w}), 961(\mathrm{w}), 939(\mathrm{w}), 895(\mathrm{w})$, 846 (w), $816(\mathrm{~m}), 795(\mathrm{~m}), 737(\mathrm{w}), 696(\mathrm{~m}), 640$ (s), 547 (m), $516(\mathrm{w}), 479(\mathrm{w}), 415(\mathrm{w})$.

\section{Synthesis of $\left[\mathrm{Co}(3-\mathrm{ampy})_{2}(\mathrm{NCS})_{2}\right](4)$}

KSCN (0.39 g, $4 \mathrm{mmol})$ and 3-aminopyridine (0.19 g, $2 \mathrm{mmol})$ were added to a solution containing $\mathrm{CoCl}_{2} \cdot 6 \mathrm{H}_{2} \mathrm{O}$ (0.48 $\mathrm{g}, 2 \mathrm{mmol})$ dissolved in distilled $\mathrm{H}_{2} \mathrm{O}(120 \mathrm{ml})$. The mixture was heated to a temperature of $80-90^{\circ} \mathrm{C}$ for $2 \mathrm{~h}$ and then filtrated while hot. The solution was stored at $40^{\circ} \mathrm{C}$ for one day where the dark blue crystals which separated were collected by filtration and air-dried (yield: $0.44 \mathrm{~g}, 60 \%)$. Anal. Calcd for $\mathrm{C}_{12} \mathrm{H}_{12} \mathrm{CoN}_{6} \mathrm{~S}_{2}(363.33 \mathrm{~g} /$ mol): $39.7 \%$ C; $3.3 \%$ H; $23.1 \%$ N; Found: $39.4 \%$ C; $3.5 \%$ H; 23.1\% N; IR (ATR, cm ${ }^{-1}$ ): 3446 (w), 3343 (w), 2090 (s), 2071 (vs), 1620 (m), 1578 (m), 1491 (m), 1444 (m), $1351(\mathrm{~m}), 1311(\mathrm{~m}), 1273(\mathrm{~m}), 1189$ (m), 1134 (m), 1058 (w), $893(\mathrm{~m}), 811(\mathrm{w}), 757(\mathrm{~m}), 712(\mathrm{~m}), 693(\mathrm{w}), 658(\mathrm{~m})$, 609 (s), $547(\mathrm{w}), 421(\mathrm{w})$. 


\section{Synthesis of $\left[\mathrm{Co}(3-\mathrm{ampy})_{4}\left(\mathrm{~N}_{3}\right)_{2}\right](5)$ and $\left[\mathrm{Co}(3-\mathrm{ampy})_{3}\right.$ $\left.\left(\mathrm{N}_{3}\right)_{3}\right](6)$}

A mixture of $\mathrm{Co}\left(\mathrm{NO}_{3}\right)_{2} \cdot 6 \mathrm{H}_{2} \mathrm{O}(0.29 \mathrm{~g}, 1 \mathrm{mmol}), \mathrm{NaN}_{3}$ $(0.13 \mathrm{~g}, 2 \mathrm{mmol})$ and 3 -aminopyridine $(0.38 \mathrm{~g}, 4 \mathrm{mmol})$ were dissolved in distilled $\mathrm{H}_{2} \mathrm{O}(140 \mathrm{ml})$ at $95{ }^{\circ} \mathrm{C}$, and the hot solution was filtered and allowed to stand at RT. The pink prism-shaped crystals which separated in the following day were collected by filtration and dried in air (yield: $0.25 \mathrm{~g}, 48 \%)$. Anal. Calcd for $\mathrm{C}_{20} \mathrm{H}_{24} \mathrm{CoN}_{14}(519.46 \mathrm{~g} /$ mol): $46.2 \%$ C; $4.7 \% \mathrm{H} ; 37.8 \% \mathrm{~N}$; Found: $46.0 \% \mathrm{C} ; 4.6 \%$ $\mathrm{H} ; 37.9 \% \mathrm{~N}$; IR (ATR, $\mathrm{cm}^{-1}$ ): 3445 (w), 3376 (w), 3319 (w), $3216(\mathrm{w}), 2052$ (vs), $1628(\mathrm{w}), 1774$ (s), 1487 (s), 1439 (s), 1342 (w), 1298 (m), 1261 (w), 1192 (w), 1134 (w), $1091(w), 1052(w), 1021(w), 978(w), 914(w)$, 880 (w), 842 (w), 802 (s), 704 (s), 639 (m), 549 (w), 525 (w), $414(\mathrm{w})$.

Slow evaporation of the mother liquor of $\mathbf{5}$ at RT resulted in the separation of fine green needle-shaped crystals of $\left[\mathrm{Co}(3 \text {-ampy })_{3}\left(\mathrm{~N}_{3}\right)_{3}\right](6)$ after three weeks. During this period, Co(II) was oxidized to Co(III) upon by aerial oxidation (yield: $0.18 \mathrm{~g}, 39 \%$ ). Anal. Calcd for $\mathrm{C}_{15} \mathrm{H}_{18} \mathrm{CoN}_{15}(467.37 \mathrm{~g} / \mathrm{mol}): 38.5 \% \mathrm{C} ; 3.9 \% \mathrm{H} ; 45.0 \%$ $\mathrm{N}$; Found: $38.3 \% \mathrm{C}$; $3.8 \% \mathrm{H}$; $45.2 \% \mathrm{~N}$; IR $\left(\right.$ ATR, $\left.\mathrm{cm}^{-1}\right)$ : 3422 (w), 3323 (w), 3213 (w), 2004 (vs), 1719 (w), 1603 (w), $1580(\mathrm{~m}), 1488(\mathrm{w}), 1447(\mathrm{w}), 1356(\mathrm{w}), 1295(\mathrm{w})$, $1264(\mathrm{w}), 1192(\mathrm{w}), 1128(\mathrm{w}), 1086(\mathrm{w}), 1059(\mathrm{w}), 1025$ (w), $908(\mathrm{w}), 879(\mathrm{w}), 799(\mathrm{~m}), 697(\mathrm{~m}), 655(\mathrm{w}), 602$ (w), $585(\mathrm{w}), 544(\mathrm{w}), 443(\mathrm{w})$.

\section{X-ray crystal structure analysis}

The X-ray single-crystal data of the six title compounds were collected on a Bruker-AXS APEX II CCD diffractometer at 100(2) K. The crystallographic data, conditions retained for the intensity data collection and some features of the structure refinements are listed in Table 1. Data collections were performed with $\mathrm{Mo}-\mathrm{K} \mu$ radiation $(\lambda=0.71073 \AA)$; data processing, Lorentz-polarization and absorption corrections were performed using APEX and the SADABS computer programs $[47,48]$. The structures were solved by direct methods and refined by fullmatrix least-squares methods on $\mathrm{F}^{2}$, using the SHELX $[49,50]$ program library. All non-hydrogen atoms were refined anisotropically. The hydrogen atoms were located from difference Fourier maps, assigned with isotropic displacement factors. Geometrical constraints (HFIX) were applied only for $\mathrm{H}$ atoms bonded to $\mathrm{C}$ atoms. Further programs used: Mercury, PLATON and ToposPro [51-53]. Packing plots are given in the supplementary section (Figs. S1-S6).

\section{Results and discussion}

\section{Synthesis, IR and UV-VIS spectroscopy}

The synthesis of the complexes $\mathbf{3}-\mathbf{5}$ was straightforward. Reactions of corresponding metal(II) salts with 3-ampy and $\mathrm{KSCN}$ (3 and 4) or $\mathrm{NaN}_{3}(\mathbf{5})$ in aqueous or aqueous methanol, afforded the corresponding title compounds. Complexes 1 and $\mathbf{2}$ were obtained by reaction of equimolar amounts of metal(II) sulfate hydrates with 3-ampy from aqueous solutions. The Co(III) azido complex 6 was obtained as by-product in the synthesis of $\mathbf{5}$ due to air oxidation of the Co(II) in the mother liquor of $\mathbf{5}$. The phase purity of the bulk material of solid compounds was checked by XRPD patterns of 1-6 (Figs S7-S12, supplementary section).

In addition to the vibrations of the pyridine moiety of the 3-ampy molecule in the complexes, the IR spectra show the characteristic bands of the pseudohalide ligands. The strong or very strong absorption bands of $\nu_{\mathrm{as}}(\mathrm{SCN})$ and $\nu_{\text {as }}\left(\mathrm{N}_{3}\right)$ in complexes 3-6 are found at $2083 \mathrm{~cm}^{-1}$ (3), at 2090 and $2071 \mathrm{~cm}^{-1}$ (4), at $2052 \mathrm{~cm}^{-1}$ (5) and at $2004 \mathrm{~cm}^{-1}(\mathbf{6})$, respectively. The weak to medium strong vibrations of the $-\mathrm{NH}_{2}$ group occur in the region $3100-3500 \mathrm{~cm}^{-1}$. In case of $\mathbf{1}$ and $\mathbf{2}$, these bands are buried by the broad band at $\sim 3180 \mathrm{~cm}^{-1}$ arising from $\mathrm{O}-\mathrm{H}$ vibrations of the lattice water molecule and aqua ligands. In $\mathbf{1}$ and $\mathbf{2}$, the ionic nature of the sulfate group is indicated by the appearance of a very strong broad band $\left(\mathrm{v}_{3}\right)$ centered around $1077 \mathrm{~cm}^{-1}(\mathbf{1}), 1077 \mathrm{~cm}^{-1}(\mathbf{2})$ and a sharp band $\left(\nu_{4}\right)$ at $609 \mathrm{~cm}^{-1}$ for 1 and $613 \mathrm{~cm}^{-1}$ for 2 [2, 28, 29, 54].

The UV-VIS spectrum of solid Ni(II) complex 1 reveals three broad bands centered at $1118 \mathrm{~nm}, 654 \mathrm{~nm}$ and $312 \mathrm{~nm}$ corresponding to the electronic transitions ${ }^{3} \mathrm{~T}_{2 \mathrm{~g}} \leftarrow{ }^{3} \mathrm{~A}_{2 \mathrm{~g}},{ }^{3} \mathrm{~T}_{1 \mathrm{~g}}(\mathrm{~F}) \leftarrow{ }^{3} \mathrm{~A}_{2 \mathrm{~g}},{ }^{3} \mathrm{~T}_{1 \mathrm{~g}}(\mathrm{P}) \leftarrow{ }^{3} \mathrm{~A}_{2 \mathrm{~g}}$, respectively, for $\mathrm{Ni}(\mathrm{II})$ in octahedral geometry [55-58]. The UV-VIS spectra of the solid Co(II) complexes $\mathbf{2 ,} \mathbf{3}$ and $\mathbf{5}$ exhibit three absorption bands at 1210,505 and $335 \mathrm{~nm}$ for $\mathbf{2}$, at 1075,500 and $372 \mathrm{~nm}$ for $\mathbf{3}$, and at 1200,520 and $372 \mathrm{~nm}$ for 5 . These bands are assigned to the electronic transitions ${ }^{4} \mathrm{~T}_{2 \mathrm{~g}}(\mathrm{~F}) \leftarrow{ }^{4} \mathrm{~T}_{2 \mathrm{~g}}(\mathrm{~F}),{ }^{4} \mathrm{~T}_{2 \mathrm{~g}}(\mathrm{P}) \leftarrow{ }^{4} \mathrm{~T}_{1 \mathrm{~g}}(\mathrm{~F})$, and ${ }^{4} \mathrm{~A}_{2 \mathrm{~g}} \leftarrow{ }^{4} \mathrm{~T}_{1 \mathrm{~g}}(\mathrm{~F})$, respectively, for $\mathrm{Co}(\mathrm{II})$ in octahedral environment [55-58]. The solid UV-VIS spectrum of Co(II) complex 4 shows absorption bands at $1340 \mathrm{~nm}, 574 \mathrm{~nm}$ and $340 \mathrm{~nm}$, which corresponds to the ${ }^{4} \mathrm{~T}_{2 \mathrm{~g}} \leftarrow{ }^{4} \mathrm{~T}_{1 \mathrm{~g}},{ }^{4} \mathrm{~A}_{2 \mathrm{~g}} \leftarrow{ }^{4} \mathrm{~T}_{1 \mathrm{~g}}(\mathrm{~F})$ and ${ }^{4} \mathrm{~T}_{1 \mathrm{~g}}(\mathrm{P}) \leftarrow{ }^{4} \mathrm{~T}_{1 \mathrm{~g}}(\mathrm{~F})$, respectively, for $\mathrm{Co}$ (II) in tetrahedral environment. The UV-VIS spectrum of solid Co(III) complex 6 shows a broad absorption band centered at $\sim 625 \mathrm{~nm}$ corresponding to ${ }^{5} \mathrm{E} \leftarrow{ }^{5} \mathrm{~T}_{2}$ transition in octahedral $\mathrm{Co}$ (III) in weak ligand field environment [55-58]. 
Table 1 Crystallographic data and processing parameters of 1-6

\begin{tabular}{|c|c|c|c|}
\hline Compound & 1 & 2 & 3 \\
\hline Empirical formula & $\mathrm{C}_{5} \mathrm{H}_{16} \mathrm{~N}_{2} \mathrm{NiO}_{9} \mathrm{~S}$ & $\mathrm{C}_{5} \mathrm{H}_{16} \mathrm{CoN}_{2} \mathrm{O}_{9} \mathrm{~S}$ & $\mathrm{C}_{22} \mathrm{H}_{24} \mathrm{CoN}_{10} \mathrm{~S}_{2}$ \\
\hline Formula mass & 383.67 & 339.19 & 551.56 \\
\hline System & Triclinic & Triclinic & Monoclinic \\
\hline Space group & $\mathrm{P}-1$ & $\mathrm{P}-1$ & $\mathrm{C} 2 / \mathrm{c}$ \\
\hline$a(\AA)$ & $7.5852(6)$ & $7.6067(4)$ & $12.5364(13)$ \\
\hline$b(\AA)$ & $8.6483(5)$ & $8.6749(4)$ & $13.5757(14)$ \\
\hline$c(\AA)$ & $10.3214(6)$ & $10.3518(5)$ & $15.7542(16)$ \\
\hline$\alpha\left(^{\circ}\right)$ & $89.346(3)$ & $89.649(3)$ & 90 \\
\hline$\beta\left(^{\circ}\right)$ & $73.671(3)$ & $73.745(3)$ & $111.848(5)$ \\
\hline$\gamma\left({ }^{\circ}\right)$ & $72.431(2)$ & $72.613(3)$ & 90 \\
\hline$V\left(\AA^{3}\right)$ & $617.46(7)$ & $623.57(5)$ & $2488.6(5)$ \\
\hline$Z$ & 2 & 2 & 4 \\
\hline$\theta \max \left({ }^{\circ}\right)$ & 30.381 & 30.169 & 33.509 \\
\hline Data collected & 46,270 & 16,402 & 85,631 \\
\hline Unique refl./ $\mathrm{R}_{\mathrm{int}}$ & $3645 / 0.0631$ & $3666 / 0.0491$ & $4825 / 0.1144$ \\
\hline Parameters/Restraints & $202 / 12$ & $202 / 12$ & $209 / 0$ \\
\hline Goodness-of-Fit on $\mathrm{F}^{2}$ & 1.071 & 1.063 & 1.176 \\
\hline$R_{1} / w R_{2}$ (all data) & $0.0360 / 0.0788$ & $0.0313 / 0.0712$ & $0.0478 / 0.1106$ \\
\hline Residual extrema $\left(\mathrm{e} / \AA^{3}\right)$ & $0.876 /-0.706$ & $0.469 /-0.551$ & $0.914 /-0.770$ \\
\hline Compound & 4 & 5 & 6 \\
\hline Empirical formula & $\mathrm{C}_{12} \mathrm{H}_{12} \mathrm{CoN}_{6} \mathrm{~S}_{2}$ & $\mathrm{C}_{20} \mathrm{H}_{24} \mathrm{CoN}_{14}$ & $\mathrm{C}_{15} \mathrm{H}_{18} \mathrm{CoN}_{15}$ \\
\hline Formula mass & 363.33 & 519.46 & 467.37 \\
\hline System & Orthorhombic & Monoclinic & Monoclinic \\
\hline Space group & Pnma & $\mathrm{P} 2_{1}$ & $\mathrm{P} 2{ }_{1} / \mathrm{c}$ \\
\hline$a(\AA)$ & $9.9591(11)$ & $7.3836(4)$ & $12.2217(8)$ \\
\hline$b(\AA)$ & $12.1512(13)$ & $19.2152(13)$ & $9.4864(7)$ \\
\hline$c(\AA)$ & $12.6272(12)$ & $8.7534(6)$ & $18.1263(13)$ \\
\hline$\beta\left({ }^{\circ}\right)$ & 90 & $108.439(3)$ & $109.543(2)$ \\
\hline$V\left(\AA^{3}\right)$ & $1528.1(3)$ & $1178.15(13)$ & $1980.5(2)$ \\
\hline $\mathrm{D}_{\text {calc }}\left(\mathrm{Mg} / \mathrm{m}^{3}\right)$ & 1.579 & 1.464 & 1.567 \\
\hline$\theta \max \left({ }^{\circ}\right)$ & 26.326 & 28.087 & 27.000 \\
\hline Data collected & 11,390 & 24,378 & 47,140 \\
\hline Unique refl./ $\mathrm{R}_{\mathrm{int}}$ & $1626 / 0.0379$ & $5480 / 0.0718$ & $4324 / 0.0369$ \\
\hline Parameters / Restraints & $112 / 2$ & $341 / 9$ & $300 / 6$ \\
\hline Goodness-of-Fit on $\mathrm{F}^{2}$ & 1.384 & 1.007 & 1.130 \\
\hline$R_{1} / w R_{2}$ (all data) & $0.0599 / 0.1090$ & $0.0429 / 0.0773$ & $0.0418 / 0.1080$ \\
\hline Residual extrema $\left(\mathrm{e} / \AA^{3}\right)$ & $0.586 /-0.608$ & $0.368 /-0.517$ & $0.887 /-0.739$ \\
\hline
\end{tabular}

\section{Description of the structures}

\section{catena- $\left\{\left[\mathrm{M}\left(\mu_{2}-3\right.\right.\right.$-ampy $\left.\left.)\left(\mathrm{H}_{2} \mathrm{O}\right)_{4}\right] \mathrm{SO}_{4} \cdot \mathrm{H}_{2} \mathrm{O}\right\} \mathrm{M}=\mathrm{Ni}(1)$ and $\mathrm{Co}(2)$}

Perspective views of the isostructural complexes $\mathbf{1}$ and 2 are given in Figs. 1 and 2, respectively, with main bond parameters are listed in Table $\mathrm{S} 1$. The structures consist of $\left[\mathrm{M}(3 \text {-ampy })\left(\mathrm{H}_{2} \mathrm{O}\right)_{4}\right]^{2+}$ cations, sulfate anions, and lattice water molecules packing. The complex cations contain two crystallographically different metal centers. $\mathrm{M}(1)$ atom is trans coordinated by two hetero $\mathrm{N}$ atoms of 3-ampy ligands [M1-N1 = 2.0979(17) for $\mathbf{1}$ and $2.1446(14) \AA$ for 2], whereas $\mathrm{M}(2)$ is trans coordinated by two amino $\mathrm{N}$ atoms of two 3-ampy molecules [M2$\mathrm{N} 2=2.1729(18)$ for 1 and 2.2253(15) $\AA$ for 2], in addition to four aqua molecules for each metal center [M-O from 2.0428(15) to 2.0819(15) $\AA$ for $\mathbf{1}$ and from 2.0546(13) to 2.1100(13) $\AA$ for 2]. The 3-aminopyridine behaves as a N,N'-bidentate bridging ligand generating $1 \mathrm{D}$ 
Fig. 1 Displacement ellipsoid plot (50\% probability) of complex 1
Fig. 2 Displacement ellipsoid plot (50\% probability) of complex 2
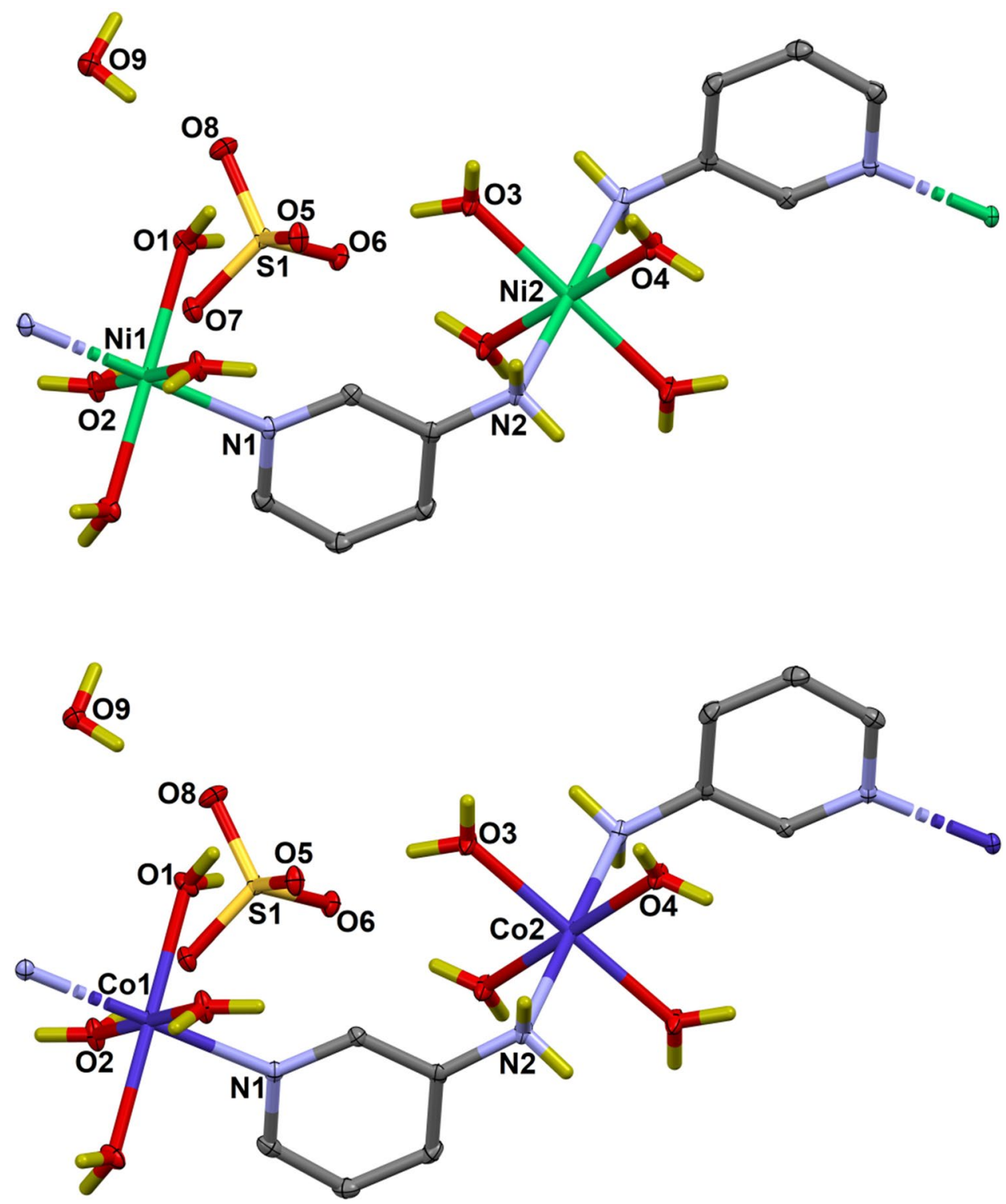

polymeric chains. The metal centers are located at inversion centers. The intrachain $\mathrm{M} \cdots \mathrm{M}$ distance is 6.7326(4) for 1 and 6.6949(5) $\AA$ for 2 and the M2-N2-C4 angles are $116.96(13)$ for $\mathbf{1}$ and $116.27(11)^{\circ}$ for 2 . The interchain metal-metal separations are 6.7706(5), 7.5852(6), 7.8462(6) § for 1 and 6.7734(4), 7.6067(4), 7.8728(4) for $\AA 2$. There are different types of hydrogen bonds consolidating the crystal structure by generating a supramolecular 3D network (Figs. S1 and S2): (1) $\mathrm{O}-\mathrm{H} \cdots \mathrm{O}$ bonds between oxygen atoms of aqua molecules and lattice water; (2) $\mathrm{O}-\mathrm{H} \cdots \mathrm{O}$ hydrogen bonds between oxygen atoms of the $\mathrm{SO}_{4}{ }^{2-}$ anion and oxygen atoms of aqua molecules and/or lattice water molecules (Table S3). Compounds $\mathbf{1}$ and $\mathbf{2}$ are isostructural to $\mathrm{Cd}(\mathrm{II})$ [2] and $\mathrm{Cu}$ (II) [12] analogous compounds.

\section{$\left[\mathrm{Co}(3-\mathrm{ampy})_{4}(\mathrm{NCS})_{2}\right](3)$ and $\left[\mathrm{Co}(3-\mathrm{ampy})_{2}(\mathrm{NCS})_{2}\right](4)$}

Coordination figures with partial atom labeling schemes for $\mathbf{3}$ and $\mathbf{4}$ are given in Figs. 3 and 4, the corresponding packing views are shown in Figs. S3 and S4, respectively, and main bond parameters are summarized in Table S2. In the monomeric compound $\mathbf{3}$, the $\mathrm{Co}$ (II) center has a trans-octahedral geometry formed by four terminal 3-ampy ligands and two terminal $\mathrm{N}$-coordinated isothiocyanate anions, whereas the distorted tetrahedron around $\mathrm{Co}$ (II) in complex $\mathbf{4}$ is formed by two 3 -ampy ligands and two terminal $\mathrm{N}$-coordinated isothiocyanate anions. The $\mathrm{Co}-\mathrm{N}$ bond lengths in $\mathbf{3}$ vary from 2.0831(14) to 2.2119(14) $\AA$, and in 4 from 1.941(4) to $2.016(3) \AA$ A. The Co-N-C and N-C-S bond angles vary from $156.89(13)$ to $170.7(4)^{\circ}$ and from $177.28(15)$ to $179.5(5)^{\circ}$; 


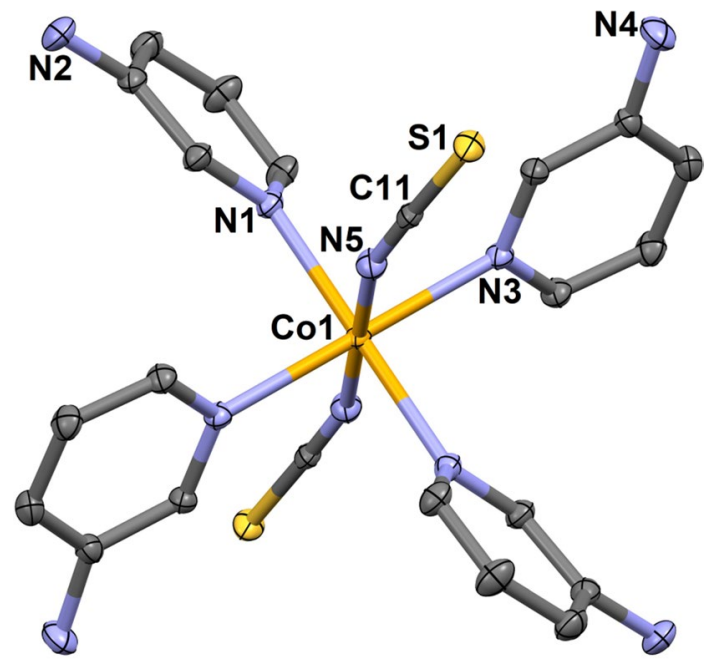

Fig. 3 Displacement ellipsoid plot (50\% probability) of complex 3

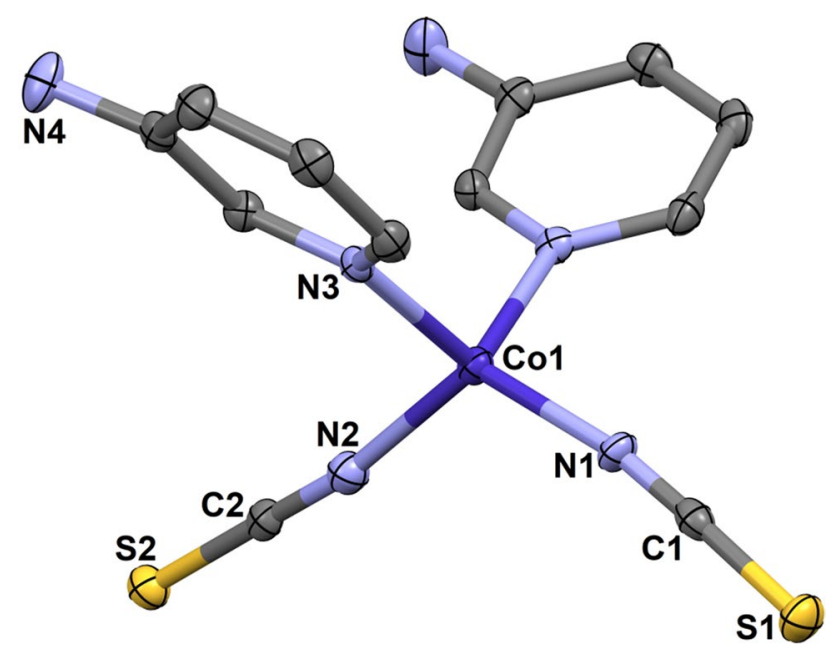

Fig. 4 Displacement ellipsoid plot (50\% probability) of complex 4

the $\mathrm{N}-\mathrm{C}$ bonds vary from $1.155(7)$ to $1.160(7)$ and $\mathrm{C}-\mathrm{S}$ bonds from $1.626(6)$ to $1.6386(16) \AA$.

\section{$\left[\mathrm{Co}(3 \text {-ampy })_{4}\left(\mathrm{~N}_{3}\right)_{2}\right](5)$ and $\left[\mathrm{Co}(3-\mathrm{ampy})_{3}\left(\mathrm{~N}_{3}\right)_{3}\right](6)$}

Coordination figures with partial atom labeling schemes for 5 and $\mathbf{6}$ are given in Figs. 5 and 6, packing views are represented in Figs. S5 and S6, respectively, and main bond parameters are summarized in Table S3. In the monomeric compound $\mathbf{5}$, the $\mathrm{Co}$ (II) center has a trans-octahedral geometry formed by four terminal 3-ampy ligands and two terminal azide anions, whereas the mer-octahedral configuration of Co(III) in complex $\mathbf{6}$ is formed by three 3 -ampy ligands and three terminal azide anions. The $\mathrm{Co}-\mathrm{N}$ bond lengths in 5 vary from 2.107(3) to 2.238(3) $\AA$, and in 6 from 1.945(2) to $1.978(2) \AA$. The $\mathrm{Co}-\mathrm{N}-\mathrm{N}$ and $\mathrm{N}-\mathrm{N}-\mathrm{N}$ bond angles vary

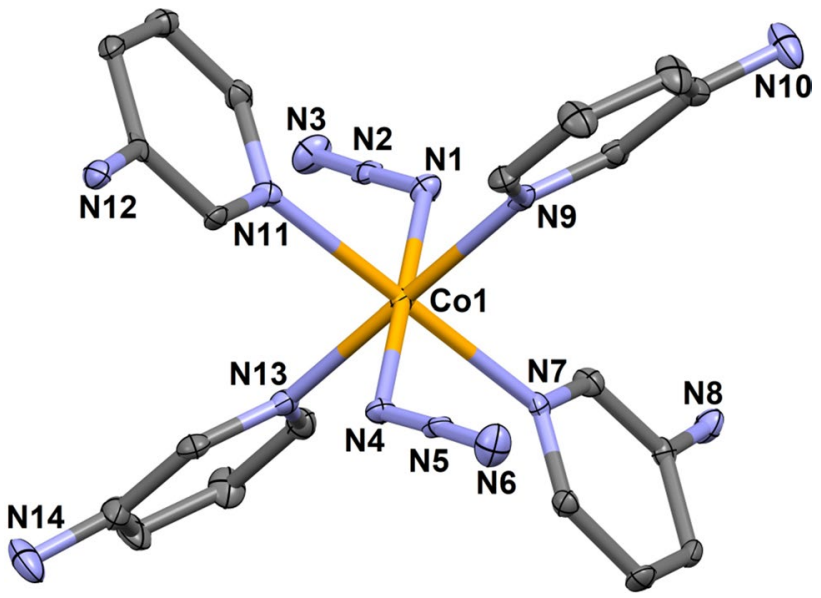

Fig. 5 Displacement ellipsoid plot (50\% probability) of complex 5

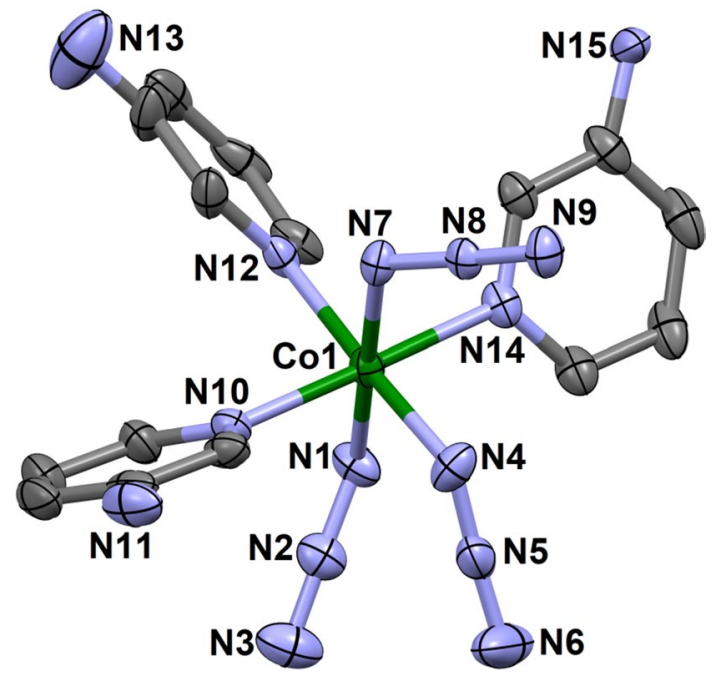

Fig. 6 Displacement ellipsoid plot (50\% probability) of complex 6

from 122.1(3) to $130.0(3)^{\circ}$ and from $175.8(3)$ to $178.3(4)^{\circ}$; the $\mathrm{N} \alpha-\mathrm{N} \beta$ from $1.182(5)$ to $1.205(3) \AA$ and $\mathrm{N} \beta-\mathrm{N} \gamma$ from 1.155 (3) to $1.182(5) \AA$ (with azido $\mathrm{N} \alpha$ atom bonded to metal center). The amino group forms hydrogen bonds of type $\mathrm{N}-\mathrm{HN}$ to non-coordinated $\mathrm{N} 4$ and $\mathrm{N} 8$ atoms of the azide anions (Table S4). Non-covalent $\pi \cdots \pi$ ring $\cdots$ ring interactions are observed between neighbouring pyridine rings (Table S5).

Analysis of hydrogen bonded networks with ToposPro 5.4.0.2 program reveal 2M4-1 for $\mathbf{1}$ and $\mathbf{2}$, sql for 3, pcu for 5 and hex topology for $\mathbf{6}$, respectively.

\section{Thermoanalytical behaviour of compounds $1-3$}

The thermogravimetric heating curves for compounds 1 and 2 are shown in Fig. 7. The Ni(II) compound 1 shows the following steps with weight losses: 
step 1: $\Delta \mathrm{m}=26.63 \%\left(80-245^{\circ} \mathrm{C}\right)$; step 2: $\Delta \mathrm{m}=6.60 \%$ $\left(245-405{ }^{\circ} \mathrm{C}\right)$; step 3: $\Delta \mathrm{m}=31.94 \%\left(405-550{ }^{\circ} \mathrm{C}\right)$; step 4: $\Delta \mathrm{m}=6.96 \%\left(550-975{ }^{\circ} \mathrm{C}\right)$. The $\mathrm{Co}(\mathrm{II})$ compound 2 shows the following steps with weight losses: step 1: $\Delta \mathrm{m}=26.38 \%\left(70-195{ }^{\circ} \mathrm{C}\right)$; step 2: $\Delta \mathrm{m}=8.58 \%$

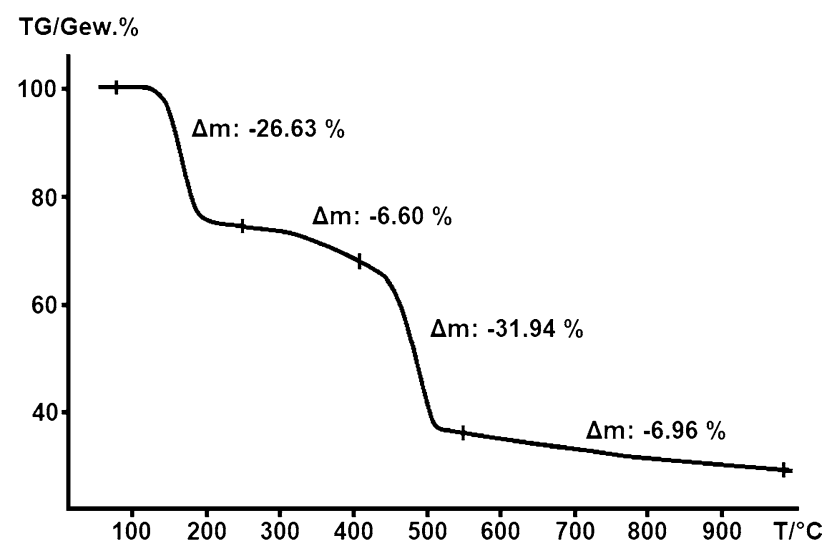

TG/Gew. $\%$

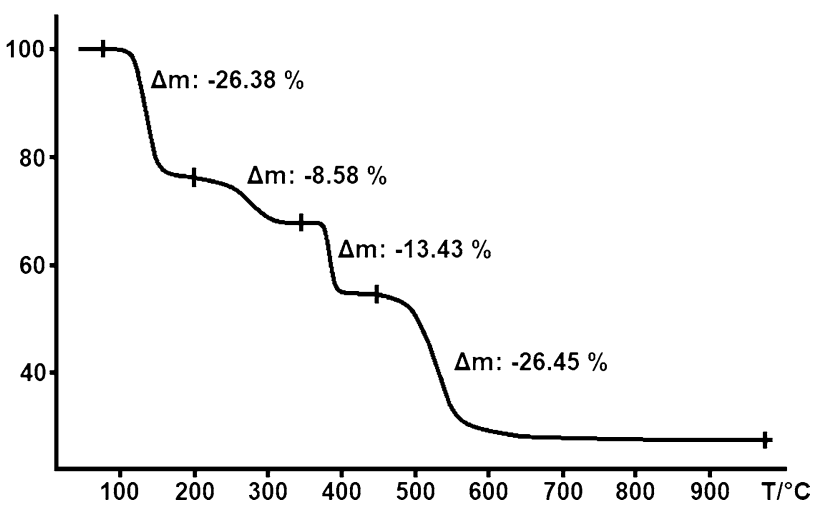

(195-340 $\left.{ }^{\circ} \mathrm{C}\right)$; step 3: $\Delta \mathrm{m}=13.43 \%\left(340-442{ }^{\circ} \mathrm{C}\right)$; step 4: $\Delta \mathrm{m}=26.45 \%\left(442-975^{\circ} \mathrm{C}\right)$. The first step of weight loss is accompanied with a sharp DSC signal at $174.2 \mathrm{C}$ and $138.8{ }^{\circ} \mathrm{C}$ for $\mathbf{1}$ and $\mathbf{2}$, respectively. The weight losses of $26.63 \%$ and $26.38 \%$ matches quite well with release of one lattice water molecule and four aqua ligands (theoretical: $26.58 \%$ and $26.56 \%$ ) for $\mathbf{1}$ and $\mathbf{2}$, respectively. The anhydrous products show further steps of weight losses by releasing the 3-ampy ligand and the decomposition of the sulfate anion. The residual mass of the $\mathrm{Ni}$ (II) sample at $975{ }^{\circ} \mathrm{C}$ is $27.87 \%$. Its PXRD pattern indicate a phase mixture with main microcrystalline components identified as $\mathrm{Ni}_{3} \mathrm{~S}_{2}$ and $\mathrm{NiO}$ (Fig. S13). The residual mass of the $\mathrm{Co}$ (II) sample of $25.16 \%$ at $975^{\circ} \mathrm{C}$ matches well with $\mathrm{Co}_{9} \mathrm{~S}_{8}$ (theoretical 24.90\%) as identified from the PXRD pattern.(Fig. S14).

The thermogravimetric heating curve for compound $\mathbf{3}$ is shown in Fig. 8. [Co(3-ampy $\left.)_{4}(\mathrm{NCS})_{2}\right]$ shows the following steps with weight losses: step 1: $\Delta \mathrm{m}=34.25 \%$ (110-220 $\left.{ }^{\circ} \mathrm{C}\right)$; step 2: $\Delta \mathrm{m}=34.17 \%\left(220-470{ }^{\circ} \mathrm{C}\right)$; step 3: $\Delta \mathrm{m}=15.25 \%\left(470-975^{\circ} \mathrm{C}\right)$. The first two steps of weight loss are accompanied with sharp DSC signals at $195.2^{\circ} \mathrm{C}$ and $341.3{ }^{\circ} \mathrm{C}$, respectively. The first step of weight loss is accompanied by color change from orange to intensive blue and PXRD pattern of sample separated at $220{ }^{\circ} \mathrm{C}$ is identical with that of $\left[\mathrm{Co}(3 \text {-ampy })_{2}(\mathrm{NCS})_{2}\right](4)$, (Fig. S15) confirming the release of two 3-ampy molecules (theoretical $34.13 \%$ ). The weight loss of second decomposition step indicates further release of remaining two 3-ampy molecules to form intermediate $\mathrm{Co}(\mathrm{NCS})_{2}$, followed by further decomposition to $\mathrm{Co}_{9} \mathrm{~S}_{8}$ at $975{ }^{\circ} \mathrm{C}$ as confirmed by PXRD (Fig. S16). (residual mass: $16.33 \%$, theoretical mass: $15.31 \%)$.

Fig. 7 Thermal behaviour of complexes 1 (top) and $\mathbf{2}$ (bottom)

Fig. 8 Thermal behaviour of complex 3

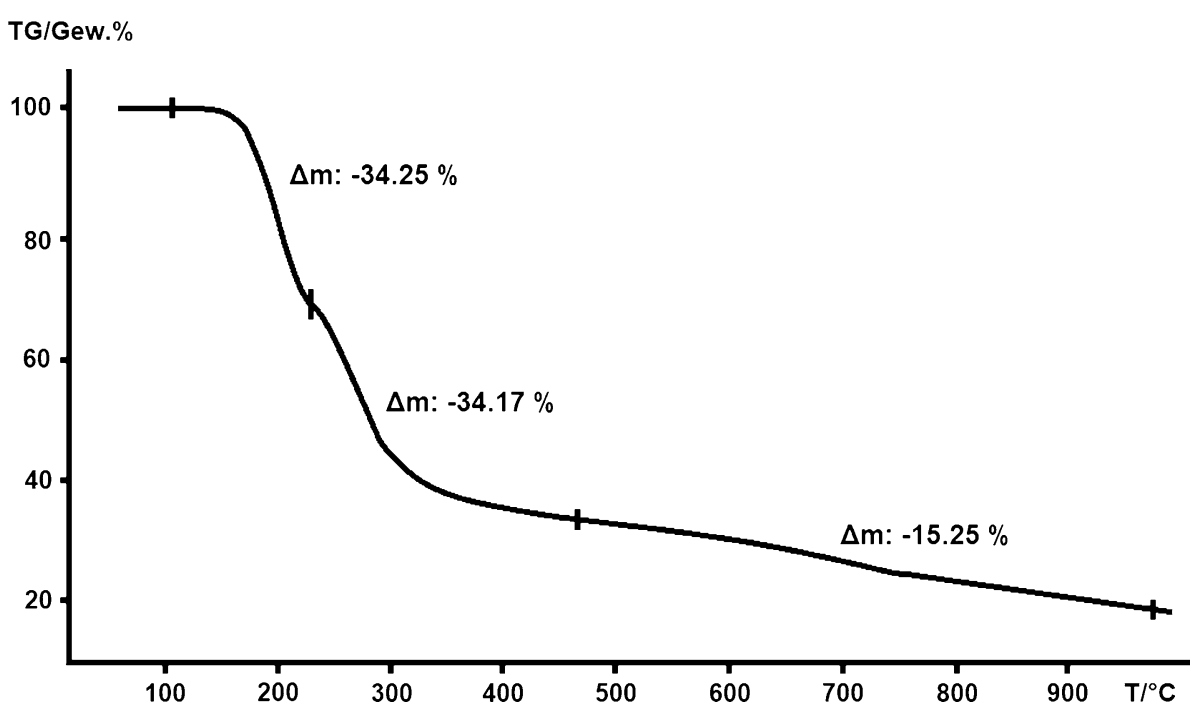


产

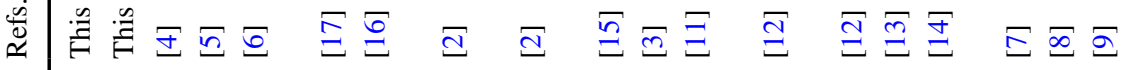

离

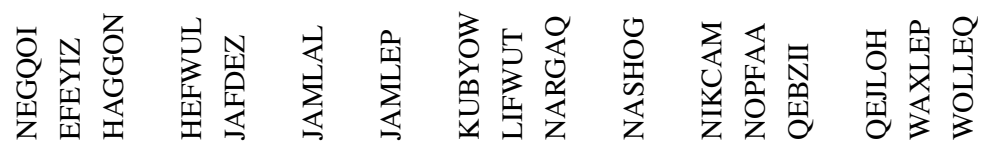
ยคลิ $ย$ คे ते ले ते คลิ तิ ते तิ

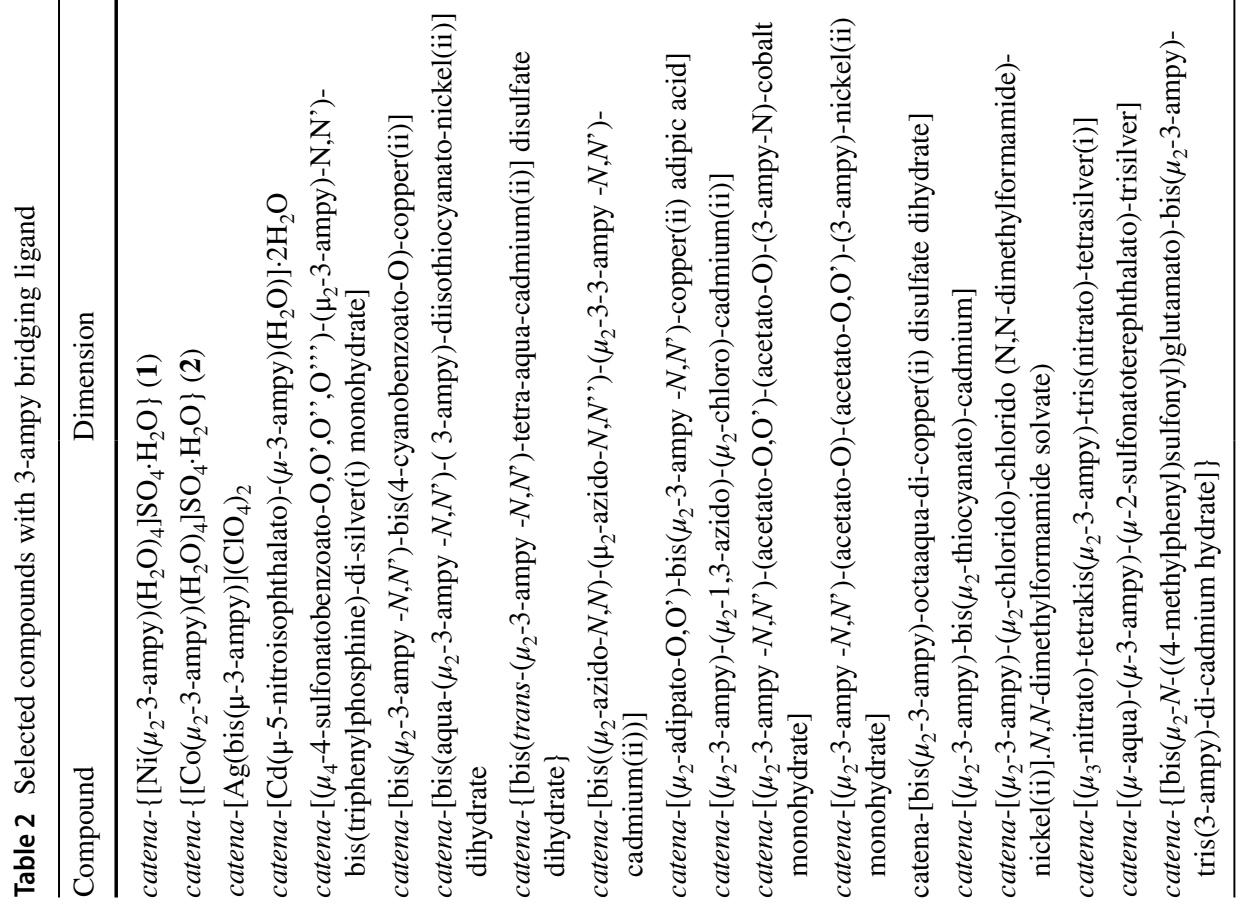




\section{Conclusions}

In this work, three coordination polymers are formed through the interaction of metal(II) salts with 3-ampy as a co-ligand namely two $1 \mathrm{D}$ systems catena- $\left\{\left[\mathrm{Ni}\left(\mu_{2}-3\right.\right.\right.$-ampy $)$ $\left.\left.\left(\mathrm{H}_{2} \mathrm{O}\right)_{4}\right] \mathrm{SO}_{4} \cdot \mathrm{H}_{2} \mathrm{O}\right\}(\mathbf{1})$ and catena- $\left\{\left[\mathrm{Co}\left(\mu_{2}-3\right.\right.\right.$-ampy) $\left.\left(\mathrm{H}_{2} \mathrm{O}\right)_{4}\right]$ $\left.\mathrm{SO}_{4} \cdot \mathrm{H}_{2} \mathrm{O}\right\}(2)$, in addition to the expected monomeric species $\left[\mathrm{Co}(3 \text {-ampy })_{4}(\mathrm{NCS})_{2}\right](3),\left[\mathrm{Co}(3 \text {-ampy })_{2}(\mathrm{NCS})_{2}\right](\mathbf{4})$, $\left[\mathrm{Co}(3 \text {-ampy })_{4}\left(\mathrm{~N}_{3}\right)_{2}\right](\mathbf{5})$ and mer- $\left[\mathrm{Co}(3 \text {-ampy })_{3}\left(\mathrm{~N}_{3}\right)_{3}\right](\mathbf{6})$, where in the latter case $\mathrm{Co}(\mathrm{II})$ was oxidized to $\mathrm{Co}(\mathrm{III})$. The isolation of the monomeric complexes through the coordination of the most basic pyridine-N-nitrogen is highly predictable. However, the 3-ampy molecule does behave as an "innocent" ligand as it looks. Surprisingly, it is the less basic amino group has very high tendency to coordinate to other metal ion and propagate the formation of polymeric chains with different dimensionality, as this was obvious in complexes $\mathbf{1}$ and $\mathbf{2}$.

In fact, the formation of CPs with 3-ampy reflects the general trend of this molecule to act as a bridging ligand through its two $\mathrm{N}$-atoms. This trend was demonstrated by the isolation of many CPs with different metal ions such as $\mathrm{Cd}(\mathrm{II}), \mathrm{Cu}(\mathrm{II}), \mathrm{Ni}(\mathrm{II}), \mathrm{Co}(\mathrm{II}), \mathrm{Ag}(\mathrm{I})$ and $\mathrm{Ag}(\mathrm{II})$ but still the highest majority were obtained with Cd(II) (Table 1). Pseudohalides used here and or those reported in Table 2 behaved as simple terminal monodentate ligands. Other carboxylate (acetate, benzoate, isophthalate, adipate) or oxyanions (nitrate, sulfonylate,...) seem to be more effective as bridging ligands in the presence of 3-ampy in expanding the network chains (Table 2). Another interesting feature is provided by the 3-ampy co-ligand in its complexes is its ability to form supramolecular hydrogen bonded systems via the $\mathrm{NH}_{2}$-group and non-covalent $\pi-\pi$ ring-ring interactions via its pyridine moiety, which adds extra stability to the resulted compounds.

Thermal analysis confirms that $\left[\mathrm{Co}(3 \text {-ampy })_{2}(\mathrm{NCS})_{2}\right]$ (4) can be obtained at $220{ }^{\circ} \mathrm{C}$ by release of two 3-ampy molecules from $\left[\mathrm{Co}(3 \text {-ampy })_{4}(\mathrm{NCS})_{2}\right](3)$ starting material. $\mathrm{Co}_{9} \mathrm{~S}_{8}$ is obtained as final decomposition product $\left(975{ }^{\circ} \mathrm{C}, \mathrm{N}_{2}\right.$ atmosphere) in case of $\mathrm{Co}(\mathrm{II})$ compounds 2 and 3 .

\section{Supplementary data}

CCDC 1982388-1982393 contains the supplementary crystallographic data for 1-6, respectively. These data can be obtained free of charge via http//www.ccdc.cam. ac.uk/conts/retrieving.html, or from the Cambridge Crystallographic Data Centre, 12 Union Road, Cambridge CB2 1EZ, UK; fax: (+44) 1223-336-033; or e-mail: deposit@ ccdc cam.ac.uk. Further supplementary data: bond parameters (Tables S1-S3), hydrogen bond systems (Table S4), non-covalent ring-ring interactions (Table S5); packing plots (Figs. S1-S6), XRD powder pattern (Figs. S7-S12), for compounds 1-6, respectively; XRD powder pattern (Figs. S13-S16) for decomposition products of 1-3, respectively.

Acknowledgements F.A.M. thanks Anna Huber and K. Gatterer (TU Graz) for assistance and NAWI Graz for partial financial support.

Funding Open access funding provided by Graz University of Technology..

\section{Compliance with ethical standards}

Conflict of interest The authors declare that there are no conflicts of interest to this work.

Open Access This article is licensed under a Creative Commons Attribution 4.0 International License, which permits use, sharing, adaptation, distribution and reproduction in any medium or format, as long as you give appropriate credit to the original author(s) and the source, provide a link to the Creative Commons licence, and indicate if changes were made. The images or other third party material in this article are included in the article's Creative Commons licence, unless indicated otherwise in a credit line to the material. If material is not included in the article's Creative Commons licence and your intended use is not permitted by statutory regulation or exceeds the permitted use, you will need to obtain permission directly from the copyright holder. To view a copy of this licence, visit http://creativecommons.org/licenses/by/4.0/.

\section{References}

1. Mautner FA, Jantscher P, Fischer RC, Torvisco A, Vicente R, Karsili TNV, Massoud SS (2019) Polyhedron 166:36-43

2. Goher MAS, Hafez AK, Abu-Youssef MAM, Badr AMA, Gspan C, Mautner FA (2004) Polyhedron 23:2349-2356

3. Mautner FA, Goher MAS, Moustafa HE, Abu-Youssef MAM, Öhrström N (2007) Polyhedron 26:2703-2712

4. Soliman SM, Elsilk SE (2017) J Mol Struct 1149:58-68

5. O'Donovan ME, LaDuca RL (2014) J Mol Struct 1070:21-27

6. Zheng X-F, Zhu L-G (2011) Z Anorg Allg Chem 637:1566-1572

7. Abu-Youssef MAM, Langer V, Öhrström L (2006) Chem Commun 10:1082-1084

8. Meng Y-T, Ruan Y-J, Mo J-P, Liu B-L, Wang A-Y, Xiao H-P (2017) Trans Met Chem 42:285-291

9. Shen Y, Ma N, Wu L, Song H-H (2015) Inorg Chim Acta 429:51-60

10. Dojer B, Pevec A, Jagodic M, Kristl M, Drofenik M (2012) Inorg Chim Acta 383:98-104

11. Dojer B, Golobic A, Jaglicic Z, Kristl M, Drofenik M (2012) Monatsh Chem 143:73-78

12. Pan W-L, Huang K-L, Xu Y-Q, Hu C-W (2007) Chin J Struct Chem 26:822

13. He X, Wei Y-Q, Li M-X (2008) Chin J Struct Chem 27:1451

14. Yeh C-W, Jou C-H, Tsou C-H, Suen M-C (2012) Acta Crystallogr Sect E Struct Rep Online 68:m1204-m1205

15. Lah N, Clérac R (2009) Polyhedron 28:2466-2472 
16. Moore MH, Nassimbeni LR, Niven ML (1987) Inorg Chim Acta 132:61-66

17. He H-Y, Zhu L-G (2006) Acta Crystallogr Sect E Struct Rep Online 62(m198):m200

18. Costes J-P, Novitchi G, Shova S, Dahan F, Donnadieu B, Tuchagues J-P (2004) Inorg Chem 43:7792-7799

19. Castillo O, Luque A, Roman P, Lloret F, Julve M (2001) Inorg Chem 40:5526-5535

20. Dutta D, Nashreul-Islam MS, Saha U, Chetry S, Guha AK, Bhattacharyya MK (2018) J Chem Cryst 48:156-163

21. Bucar D-K, Mestrovic E (2003) Acta Crystallogr Sect E: Struct Rep Online 59:m985-m987

22. Youssef MA, Escuer A, Goher MAS, Mautner FA, Vicente R (2000) J Chem Soc Dalton Trans 413:413-416

23. Pandey P, Kharediya B, Elrez B, Sutter J-P, Bhargavi G, Rajasekharan MV, Sunkari SS (2017) Dalton Trans 46:15908-15918

24. Arumuganathan T, Rao AS, Das SK (2010) Cryst Growth Des 10:4272-4284

25. Izumi HK, Kirsch JE, Stern CL, Poeppelmeier KR (2005) Inorg Chem 44:884-895

26. Lah N, Leban I (2005) Acta Crystallogr Sect E Struct Rep Online 61:m1708-m1710

27. Fang X, Yang F-J, Yu H-Y, Chen N-S, Huang M-D, Wang J-D (2009) Inorg Chem Commun 12:664-666

28. Mautner FA, Berger C, Gspan C, Study B, Fischer RC, Massoud SS (2017) Polyhedron 130:136-144

29. Abu-Youssef MAM, Escuer A, Langer V (2006) Eur J Inorg Chem $16: 3177-3184$

30. Todd AM, Swinburne AN, Goeta AE, Steed JW (2013) New J Chem 37:89-96

31. Fomina I, Dobrokhotova Z, Aleksandrov G, Bogomyakov A, Fedin M, Dolganov A, Magdesieva T, Novotortsev V, Eremenko I (2010) Polyhedron 29:1734-1746

32. Wu J-Y, Feng D-M, He H-Y, Wang Q-X, Zhu L-G (2005) Acta Crystallogr Sect E Struct Rep Online 61:m1779-m1781

33. He H-Y, Zhu L-G (2003) Acta Crystallogr Sect E Struct Rep Online 59:m1192-m1193

34. Kartal Z, Sahin O, Yavuz A (2018) J Mol Struct 1171:578-586

35. Saha S, Kottalanka RK, Bhowmik P, Jana S, Harms K, Panda TK, Chattopadhyay S, Nayek HP (2014) J Mol Struct 1061:26-31

36. Kojima T, Nakanishi T, Honda T, Harada R, Shiro M, Fukuzumi S (2009) Eur J Inorg Chem 6:727-734

37. Willett RD, Halvorson K (1988) Acta Crystallogr Sect C Cryst Struct Commun 44:2068-2071
38. Ilyukhin AB, Koroteev PS, Novotortsev VM (2019) J Mol Struct 1187:38-49

39. Medved'ko AV, Churakov AV, Yu H, Li W, Vatsadze SZ (2017) Acta Crystallogr. Sect E Cryst Commun 73:856-858

40. Peng Z-S, Zhang C-L, Shen X-M, Deng Q, Cai T-J (2011) J Coord Chem 64:2848-2858

41. Roman P, Luque A, Beitia JI, Guzman-Miralles C (1992) Polyhedron 11:1883-1890

42. Deng Q, Huang Y, Peng Z, Dai Z, Lin M, Cai T (2013) J Solid State Chem 200:60-69

43. Cherif I, Zid MF, El-Ghozzi M, Avignant D (2012) Acta Crystallogr Sect E Struct Rep Online 68:m900-m901

44. Willett RD, Place H, Middleton M (1988) J Am Chem Soc 110:8639-8650

45. Blanchette JT, Willett RD (1988) InorgChem 27:843-849

46. Ali BF, Al-Far RH, Haddad SF (2008) Acta Crystallogr Sect E Struct Rep Online 64:m751-m752

47. Bruker (2005) SAINT v. 7.23; Bruker (2006) APEX 2, v. 2.0-2, Bruker AXS Inc., Madison, Wisconsin, USA, 2005

48. Sheldrick GM (2001) SADABS v. 2, University of Goettingen, Germany

49. Sheldrick GM (2008) Acta Crystallogr, A 64:112-122

50. Sheldrick GM (2015) Acta Crystallogr, C 71:3-8

51. Macrae CF, Edington PR, McCabe P, Pidcock E, Shields GP, Taylor R, Towler T, Van de Streek J (2006) J Appl Cryst 39:453-457

52. Speck AL (2001) PLATON, a multipurpose crystallographic tool. Utrecht University, Utrecht The Netherlands

53. V.A. Blatov, A.P. Shevchenko, D.M. Proserpio. ToposPro: Applied topological analysis of crystal structures with the program ToposPro (2014) Cryst Growth Des, 14: 3576-3586. (v. 5.4.0.2, realease date: 21.04 .2020$)$

54. Nakamoto K (1978) Infrared spectra of inorganic and coordination compounds, 2nd edn. Wiley, New York

55. Henderson B, Imbusch GF (1989) Optical spectroscopy of inorganic solids. Oxford Science Publications, Oxford

56. Racah G (1942) Phy Rev 62:438-462

57. Tanabe Y, Sugano S (1954) J Phy Soc Japan 9:753-765

58. Housecroft CE, Sharpe AG (2012) Inorganic chemistry, 4th edn. Pearson Publisher, Harlow, England, p 691

Publisher's Note Springer Nature remains neutral with regard to jurisdictional claims in published maps and institutional affiliations. 